\title{
COVID-19 AND THE U.S. HEALTH CARE INDUSTRY: TOWARDS A "CRITICAL HEALTH CRIMINOLOGY” WITHIN STATE CRIME STUDIES
}

\author{
David O. Friedrichs and Valeria Vegh Weis
}

\begin{abstract}
The core claim of this article is that critical criminology offers us an especially potent framework for interpreting state-corporate crime with the health care industry in the United States as one illustrative case, particularly in the context of the COVID19 crisis. The unprecedented, surreal pandemic crisis that surfaced in 2020 brought into especially sharp relief many of the core claims of critical criminology in relation to domination, inequality and injustice within a contemporary capitalist political economy, while it also raised the need to broaden critical criminology studies to incorporate the specificities of the health care systems and the pharmaceutical industry. Following this challenge, the article proposes to foster a "critical health criminology" within statecorporate crime research. To do so, this article explores the "big picture" in relation to the COVID-19 pandemic crisis and reveals how it can be understood as a criminological phenomenon. Such a project incorporates the identification of some conceptual issues requiring attention in relation to advancing an enriched form of criminological analysis in these times, and toward building a foundation for a more fully realized twenty-first century criminology.
\end{abstract}

Keywords: critical criminology; state-corporate crime; COVID-19 pandemic crisis; health care industry; pharmaceutical industry

\section{Preface: Moses Taylor Hospital and COVID-19}

On April 11, 2020, The Washington Post published a front-page article entitled "Amid chaos, anguished nurses say Pennsylvania hospital risked infecting cancer patients, babies and staff with covid-19" (Butler 2020). The article reported that "[s]ome nurses were going directly from treating covid patients to administering chemotherapy to cancer patients, who would be especially endangered by a

David O. Friedrichs, Author, Trusted Criminals

Valeria Vegh Weis Alexander von Humboldt, Postdoctoral Fellow at Freie Universität Berlin; Buenos Aires University Law School 
covid-19 infection." They were also moving between units with patients who had been diagnosed with this disease, or were being investigated for possible infection, and neonatal units. Asked by reporters, the nurses alleged that medical staff, as well as patients, were not provided with the necessary protective equipment and that preventive procedures were not in place. A statement issued on behalf of the hospital's CEO took exception to these allegations, and representatives for the hospital claimed that the accusations were instigated by the health workers' union "for its own purposes" (Bolus 2020).

The hospital in question is the Moses Taylor Hospital in Scranton, a small city in the northeast part of Pennsylvania. The hospital itself is owned by a Tennesseebased corporation, CHS (Community Health Systems), a "parent" holding company for various health-related facilities. The CEO of CHS, Michael Brown, was reported to have earned $\$ 8$ million in compensation the previous year (Butler 2020). He was not being rewarded for enhancing the quality of patient care at the hospitals and nursing homes, or for coming up with a cure for cancer. He was solely being rewarded for his perceived skill (and board of trustees' connections) in overseeing the realization of the best possible financial return for shareholders (and disproportionately, for top executives) in the corporation he headed. The hospital itself was classified as "for profit," which is of course one dimension of the widespread critique of the U.S. health care system, which has a huge private profit-seeking sector, unlike almost all other "advanced" Western countries.

This story is reflective of some of the darker dimensions of "predatory capitalism" (i.e., an economic system where "the few" profit at the expense of everyone else), which privileges those with excellent insurance and deep pockets over those in great need of good medical care but without the financial resources to obtain it (Rosenthal 2020; Slobodian 2020). So far, the COVID-19 pandemic has cast these issues into an especially sharp light, exposing the criminal dimension of the forprofit health complex in a clearer manner: if the allegations made by some nurses in this case were in fact true, and if patients and staff members were infected with COVID-19 and subsequently died as a consequence, would some form of homicide prosecutions directed at the executive officers of CHS be appropriate? Do such allegations go beyond the possibility of some form of civil liability, and reflect instead some form of criminal wrongdoing, even if only in the form of criminal negligence? And more broadly still: does the profit-driven health care industry in the United States, dominated by large-scale organizations operating with the core support of powerful politicians, demonstrate in an especially potent way the "structural violence" and inherent criminality of a capitalist system (Gordon and Green 2020)? In historical terms, will the current pandemic be viewed as having contributed to a broader and ultimately transformative public consciousness of this structural violence and criminality? 
As it happens, one of the authors was a weekly patient in the chemotherapy infusion unit of Moses Taylor Hospital between February 25 and March 31, 2020 and directly observed some practices that appeared to be unsafe and in line with the nurses' allegations. To the best of his knowledge, he did not become infected with COVID-19 as a consequence of his chemotherapy treatments, but even so. And as someone who had published quite extensively over the course of several decades on crimes of corporations (Friedrichs 2010), he was struck by the potential irony involved if he did in fact become infected and suffer a fatal outcome. A possible "news of the weird" headline: "Criminologist who published on crimes of corporations killed by state-corporate crime."

\section{Introduction}

Beyond the vast avalanche of journalistic reporting and commentary on the COVID-19 pandemic crisis, it has attracted the attention of biologists, epidemiologists, virologists, ecologists, historians, economists, political scientists, sociologists and in fact academics and specialists from a broad range of contemporary disciplines and fields. Our concern here is to address some core criminological dimensions of the pandemic.

This article does so as an unapologetic exercise of "big picture" criminology (Rosenfeld 2011): the purpose here is not to examine in depth a specific criminological phenomenon - the focus of most criminological scholarship — but rather to explore the larger context within which immensely consequential criminological phenomena are best understood. In relation to a "big picture" prism, this article addresses the potential challenge of COVID-19 for criminology and particularly on the potential of critical criminology as a platform to address the pandemic with a focus on what might be referred as "critical health criminology." The article later addresses the U.S. health care system - and, within it, the U.S. pharmaceutical industry - as a possible case study of state-corporate crime in relation to COVID-19. Insofar as the U.S. health care system (including its pharmaceutical industry) is thoroughly interdependent with governmental entities, a state-corporate crime analysis is essential. Finally, concluding thoughts on the future of criminology are presented.

\section{The Field of Criminology and COVID-19: Towards an Invisible Enemy?}

Criminology as a multi-disciplinary field of inquiry has been regarded at its core as focused upon the bad (illegal) actions of individuals, gangs and organizations, and the societal response to these actions. Criminals - and criminal entities — although 
they typically go to some lengths to conceal their criminal activity from representatives of the state and the social order, are nevertheless "visible" as human beings. At the same time, fear of being a victim of crime, and of perceived criminals in particular, has also been an enduring dimension of human social existence in all developed societies, with immense consequences in terms of public policy and social interaction, and therefore one core focus of criminology. There are many forces that influence the perception of crime, mainly in terms of individual acts, but criminology has been disproportionately focused historically on crimes committed by the poor and powerless (Reiman and Leighton 2020; Reiner 2016; Vegh Weis 2017).

In contrast, in a new COVID-19 era, fear is less concentrated on the ordinary "visible crimes and criminals," but instead is more focused on an "invisible crime" and an "invisible enemy," i.e. the virus. In terms of "invisible crimes," some British criminologists have called for more attention to those hugely harmful human activities that are for various reasons less visible as crimes than conventional forms of criminal violence, in part because they precipitate social death over long periods of time, but not with the immediacy of common homicides (Hillyard et al. 2004; Davies et al. 2014; Gordon and Green 2020). As to the "invisible enemy" of COVID-19, it is associated first with the natural world and has its source, apparently, in the animal world (in this case, bats). Natural scientists with a range of different specializations-from epidemiology to infectious disease researchers- have been at the front line in the "war" against COVID-19. A range of human decision-makers is involved in instituting policies and practices to ideally limit the spread of COVID-19, to organize the most effective response to it, and to specifically address the vast range of economic consequences of this pandemic. But where are criminologists in all of this?

Mainstream (or "orthodox") criminological research is sure to be affected by the COVID-19 pandemic crisis, with empirical investigations of the impact of the crisis across a range of criminological concerns, from patterns of criminal behaviour to changes in penal policies. Mainstream criminology addresses forms of crime - including but hardly limited to, homicide, assault, rape, burglary, robbery and theft-with regard to which there is a high level of societal consensus that harm is involved, that the status of these activities as "crimes" is wholly appropriate, and that the most effective (and just) criminal justice responses need to be identified, analysed and implemented.

Indeed, it was recognized early on that COVID-19 would have some impact on patterns of criminal behaviour. For example, some data early in the crisis indicated that, with people in large numbers "sheltering" at home but away from businesses, home burglaries decreased but those directed at businesses increased (MacFarquhar and Kovaleski 2020). Conditions of living in close quarters under stressful circumstances were expected to lead to an increase of domestic violence (or intimate 
partner violence) cases. Altogether, the "opportunity structure" for a wide range of delinquent and criminal conduct was being transformed by the pandemic.

As to the criminal justice system itself, criminologist Ezzat Fattah (2020) suggested early on that it was being "upended" by the pandemic. There were indications that police in some locations were modifying their approach to enforcement, delaying arrests or refraining from acting in response to nonviolent crimes. Court proceedings were having to make various types of adaptations, with courthouses closed down. And it was easily recognized that the conditions of prisons and jails were especially conducive to promoting COVID-19 infections. They were in fact "death traps" for both people serving time and staff. In some jurisdictions, prisoners who met certain criteria were being released early to minimize contagion. If contracting COVID-19 put people in prison-especially those who were older, and with "underlying" health conditions - at serious risk for a fatal outcome, questions in relation to justice, understood as an ethical and moral value, arose: i.e., should someone serving a jail or prison sentence - especially as is typically the case, not for a "heinous" crime-be subjected to "capital" punishment by COVID-19? More broadly, there was speculation on whether the vast number of citizens enduring involuntary confinement conditions themselves, due to "sheltering in place" orders, would become more empathetic toward those enduring incarceration, and whether, if so, this would lead to an acceleration of de-incarceration.

However, three relevant limitations of the mainstream framework have been brought into especially sharp relief by the pandemic. First, mainstream criminology treats the formal legal order's characterization of "crime" as unproblematic, as it does the basic structure of the existing political economy (Reiner 2016; Vegh Weis 2017). Accordingly, it reinforces a long historical tradition of highlighting some forms of harm, for example, those disproportionally committed by the poor and the powerless, while either marginalizing or wholly neglecting other forms of harm, for example, those wholly committed by the rich and the powerful. Moreover, mainstream criminology also reinforces broad public and popular understandings of "who are the criminals" (Hagan 2010) that foster disproportionate attention to and harshness in relation to certain classes of offenders (e.g., illegal immigrants and inner city minorities who commit conventional crimes) and inattention to and excessive lenience to other classes of offenders (e.g., political leaders and corporations who perpetuate crimes of states and corporate crimes) (Michalowski 2009; Reiman and Leighton 2020). One of the authors introduced some years ago an "inverse hypothesis": i.e., the level of criminological attention to a form of crime varies inversely with the level of harm caused by such crime (Friedrichs 2007: 5). If such a hypothesis, taken literally, is overly simplistic and one-dimensional, the claim here is that it incorporates a core truth. 
Second, mainstream criminology takes the existing political and social status quo as a given and does not specifically address this context in relation to crime and criminal justice. Thus, it lends support-either intentionally, or by default-to an existing political economy that perpetuates pervasive forms of domination, oppression and inequality (Barak 2015; Rothe and Kauzlarich 2016b; Vegh Weis 2017). Moreover, as Meda Chesney-Lind (2019) —a recent president of the American Society of Criminology, and a critical criminologist-has observed, the field of criminology, historically, has addressed crime principally as a local phenomenon. Increasingly, a global and transnational criminology has called for transcending such parochialism, and the coronavirus pandemic crisis potently reinforces the need to do so.

Third, mainstream criminology as it exists today tends to operate within "silos" of specialization, focusing on narrowly framed dimensions of crime and criminal justice, with much scholarship addressed to — and principally referencing-fellow specialists within the field of criminology. The pandemic produced an especially forceful reminder of the fact that the complex, multi-faceted, larger context within which crime and criminal justice plays out is hugely consequential.

When it addresses the health care industry, the limitations of mainstream criminology become especially clear. To exemplify, an article entitled "Health Criminology: New Developments in an Emerging Paradigm" published in the May/June 2020 issue of The Criminologist addresses the impact of health-related issues on involvement in conventional delinquent and criminal activity, and the impact of criminal justice processing and incarceration in relation to health-related issues (Vaughn et al. 2020). We can certainly acknowledge that health issues intersect with crime and criminal justice in significant ways, and a "health criminology" might usefully address historically marginalized dimensions of such intersection. But the focus of the article is on conventional offenders in relation to health and crime, while once again the crimes of the powerful in the health industry are missing. There is no acknowledgement within the "health criminology" article of the claim that the health care system as it is presently organized in the USA incorporates significant dimensions of a criminal enterprise. Accordingly, in what follows we address how a critical criminological perspective can effectively address this limitation of mainstream criminology in general and particularly in relation to "health criminology." Or, in other words, what could a critical health criminology look like?

\section{Critical Criminology and COVID-19: Towards a "Critical Health Criminology"}

Critical criminology shows that crime does not occur within a vacuum, but rather within the context of what is happening within the larger political economy. 
This context is characterized today by political, economic and social inequality, as well as relations of domination and oppression within the contemporary capitalist political economy. Within this context the pandemic has caused even more catastrophic consequences on multiple different levels, which are well known and need hardly be spelled out here. Critical criminology has been characterized as having as its core mission the critique of domination, oppression and inequality, in all of its multiple manifestations (DeKeseredy and Dragiewicz 2018; Michalowski 1996; Schwartz and Brownstein 2016; Ugwudike 2015). The COVID-19 pandemic crisis brings domination, oppression and inequality into especially sharp relief, and has rendered more visible structural dimensions of the neoliberal global political economy.

Furthermore, it is within the tradition of critical criminology — which evolved in fundamental ways out of radical and neo-Marxist criminology - that the foundations for a twenty-first century criminology that highlights the crimes of the powerful and corrects for the disproportionate criminological attention to the crimes of the powerless is to be found (Barak 2015; Bittle et al. 2018; Rothe and Kauzlarich 2016b; Ruggiero 2015). While critical criminology has not been immune to the "silo" and internally focused tendencies of mainstream criminology identified above, we submit that altogether it has been more fully engaged with the broader context of the political economy. The pandemic seems early on to be impacting the political economy in hugely consequential ways, and so offers us a unique context for advancing the transformation of the field of criminology in a productive way.

In this vein, while the pandemic confronts us all with an "invisible" enemy, it might also open an opportunity to focus on "invisible" crimes that - as opposed to the ones committed by the "visible" poor and which might directly affect people a few times in a lifetime - affect us all on a daily basis and in a systematic manner (Davies et al. 2014). Many governments, especially those with autocratic leadership, are failing to protect the lives of their citizens, shedding light onto ordinarily invisible "state crime" in some form (Chambliss et al. 2010; Green and Ward 2004; Rothe 2009; Rothe and Kauzlarich 2016a). Corporations-including those in the financial sector, such as banks - are taking advantage unfairly of government financial relief programs, and of small business competitors, employees and consumers, exposing the traditionally invisible "corporate crime" as associated with the COVID-19 pandemic crisis (Silver-Greenberg et al. 2020a). Cooperation between the state and corporations to hide the extent of the pandemic has exposed the extent of invisible "state-corporate crime" and the true scope of state-corporate crime symbiosis (Michalowski and Kramer 2006; Friedrichs and Rothe 2014; Ghazi-Tehrani 2019; Tombs 2012). Raymond J. Michalowski and Ronald C. Kramer (2006: 3) have defined "state-corporate" 
crime (a term they originally introduced in 1990) as a concept that "seeks to breach the conceptual wall between economic crimes and political crimes in order to create a new lens through which we can examine the ways crimes and social injuries often emerge from intersections of economic and political power." If the claim is ultimately documented that the World Health Organization (WHO) had some responsibility for the scope of the pandemic by virtue of its alleged corrupt ties with China, from which the COVID-19 pandemic originated, this could be associated with usually invisible "crimes of globalization," i.e. those demonstrably harmful policies and practices of institutions and entities that are specifically a product of the forces of globalization, and that by their very nature occur within a global context (Rothe and Friedrichs 2015). But there are surely other significant global dimensions of criminality in relation to the pandemic, including International Monetary Fund pressure to third world countries struggling to pay their external debt instead of devoting their meagre existing budgets to confront the pandemic and avoid unnecessary deaths.

Within the critical vision of the status quo and the broad range of crimes of the powerful, critical criminology provides us with an especially appropriate and potent framework to address the health care industry in times of pandemic as statecorporate crime under the framework of "critical health criminology." We should note here that this is not a wholly new initiative, even if this particular labelling has not been applied to it. For example, Jeffrey Reiman and Paul Leighton (2020), in multiple editions of the classic text The Rich Get Richer and the Poor Get Prison (with early editions authored by Reiman only), addressed "How Health Care May Be Dangerous to Your Health." O. Hayden Griffin and Bryan Lee Miller (2010) have specifically addressed the OxyContin catastrophe in the United States in relation to state-corporate crime, as a governmental failure to adequately regulate pharmaceutical companies. More recently Raymond Michalowski and Meredith Brown (2020) have addressed the "poisonous" consequences of regulatory rollback in the Trump era on public health. Other such examples could be identified. Our objective here is to further develop such incipient "critical health criminology" initiatives specifically in relation to the pandemic.

\section{The U.S. Health Care Industry: A Case Study of "Critical Health Criminology" within State-Corporate Crime in the Context of COVID-19?}

The health care industry in the United States is a vast enterprise. Large numbers of dedicated, highly educated and trained professionals - doctors, nurses and a whole range of other health care workers - provide hundreds of millions of people with health care that is sophisticated in at least some dimensions (Saphier 2020). Many 
people can then live relatively pain-free, productive and long lives. A vast apparatus of institutions and organizations - from hospitals to health insurance plans supports this enterprise. Pharmaceutical companies, as part of this industry, devote billions of dollars to producing a wide range of innovative and sometimes effective drugs to treat every imaginable ailment and health problem.

Specifically, within the context of a pandemic, the heroism of health care workers in all capacities - as well as researchers within the pharmaceutical industryworking long hours, with much dedication, and in many cases putting themselves at huge risk - was justly celebrated. Altogether, this whole health care enterprise could hardly be more different from that of organized crime entities, of drug cartels and gangs, and conventional criminal enterprises of any kind. At least all of what is stated in the foregoing is the implicit, if not explicit, claim of the health care industry, and those who support and praise it.

Alternatively, a vast literature on the profound deficiencies of the U.S. health care system has developed, along with a huge volume of on-going political and public discussion in relation to these deficiencies (Bogdanich 1991; Brill 2015; Case and Deaton 2020a, 2020b; Nussbaum 1990). It is not our purpose here to replicate this widely diffused critique, or engage with the massive relevant literature and commentary. Rather, our purpose is to specifically reframe the core issues in criminological terms building upon the concept of state-corporate crime. The overall objective is to contribute, however modestly, to the aspirational project of transforming both the core character of twenty-first century criminological inquiry, and to an endeavour that cuts across a broad range of disciplines with the goal of accelerating the inevitable transformation of U.S. health care into a fundamentally just and effective-and not profit-driven - enterprise. As Elizabeth Rosenthal has noted:

In our market-based system, hospitals are primed to compete, not cooperate ... In the past quarter century, we have developed a reimbursement system that showers cash on elective and specialty care and discourages hospitals from serving the basic health needs of society ... the system we need now is one that responds more to illness and less to profits (2020: 29).

What are the core dysfunctions and deficiencies of U.S. health care, stated as concisely as possible? As William Hsiao (2020) informs us, in a recent year, U.S. citizens spent over $\$ 10,000$, per person, on average, for health care; i.e. twice what other advanced countries spend, despite the fact that they have much better outcomes in relation to life expectancy, infancy mortality and the prevalence of various serious health conditions. Experts estimate that some 30 percent (or about \$1 trillion) of the vast expenditure of money on health care in the United States is 
wasted in various ways, including some $\$ 150$ billion in unnecessary treatment, and specifically in relation to fraud. Altogether, there are huge medical pricing mark-ups and many incentives to "game" the system in the interest of profit.

Moreover, the United States is the only country with an advanced economy without some form of universal health care coverage. All of these other countries treat health care as a "social good," not as a "commercial product," which is the case for the United States. In the latter country, health care is more equivalent to such services and products as being served at a high-end restaurant or obtaining fancy jewellery, as opposed to as a basic human right. A physician and bioethicist, Jacob Appel (2011), has characterized private health insurance in the United States as a large-scale criminal endeavour that should in fact be criminalized. It extracts hundreds of billions of dollars from its customers, often denies claims they submit, and rewards its top executives extravagantly. It has more in common with predatory schemes such as loansharking than it does with fire insurance. And some 28 million U.S. citizens are uninsured, with an additional 44 million U.S. citizens underinsured. Millions forego basic health treatment-including for childrendue to this circumstance, and of those who do seek treatment at least a half a million are driven into personal bankruptcy annually due to medical bills they cannot pay. Altogether, while U.S. above can provide very good outcomes for the wealthy and the well-insured, it is profoundly inequitable, and for the most part the less well-off suffer accordingly.

Within the U.S. health care system, the pharmaceutical industry is a core component that brings into especially sharp relief the criminogenic dimensions. Every year some $\$ 1$ trillion dollars is spent on pharmaceutical industry drugs in the country (Goldacre 2013; Posner 2020). Since the middle of the twentieth century, it has been one of the most profitable industries in this country, and by some measures the single most profitable industry. However, John Braithwaite's (1984) Corporate Crime in the Pharmaceutical Industry, is a classic contribution to the criminological literature exposing the "dark" side of this industry. As with private health insurance, the pharmaceutical industry has been described as a "criminal enterprise," due to its wide range of exploitative, corrupt and deceptive practices (Zorn 2015). In one notorious case several years ago, the price per tablet of one pharmaceutical product was raised overnight from $\$ 13.50$ to $\$ 750$.

Illicit drugs - including heroin, cocaine and marijuana - became a huge focus of the U.S. criminal justice system, especially in the last couple of decades of the twentieth century, with vast numbers of those involved in trafficking it (disproportionally inner city, minority group men) going to prison for long periods of time (Caulkins and Reuter 2017). But the pharmaceutical industry has a very long history of profitable promotion of addictive drugs (Posner 2020). It is not widely known among the general public that early in the last century the pharmaceutical 
industry sold and actively promoted heroin, with claims of various beneficial dimensions of a drug that ultimately acquired major criminalized associations, with users profoundly stigmatized as "junkies."

In more recent times the pharmaceutical industry has aggressively promoted the over-prescription of Valium, menopause treatments, anti-depressants and pain killers, among other pharmaceutical products, for vast profits (Goldacre 2013; Posner 2020). These over-uses have had a range of harmful - and sometimes fatal - consequences, as has been true of a vast over-prescription of antibiotics, with up to 90 percent being unnecessary. By 2020, at least 200,000 U.S. deaths - a staggering number - had been attributed to opioid use (Case and Deaton 2020a, 2020b). Most notoriously, Purdue Pharma-founded by three physician brothers with the name of Sackler-became the "poster case" for the complicity of the pharmaceutical industry in the massive devastation associated with opioid addiction in the early part of the twenty-first century (Macy 2018). Much evidence eventually surfaced documenting the aggressive promotion of OxyContin by this pharmaceutical company-including by members of the Sackler family - while marginalizing or concealing emerging evidence of its profoundly addictive qualities.

As early as 2007 , three executives of this company pleaded guilty to criminal charges in relation to deceptive marketing practices, and the company paid over $\$ 600$ million in fines and other charges (Griffin and Miller 2010). The Sackler family itself, however, continued to receive much acclaim as philanthropistswith buildings and halls in cultural, educational and medical institutions named for them-while transferring billions of dollars of their profits into off-shore accounts, to protect this money from lawsuits directed at their company (Hakim et al. 2019; Metcalf et al. 2019). The difference between the fate of members of the Sackler family and inner-city drug dealers is exceptionally striking, despite the fact that in both cases they were selling hugely harmful drugs to vulnerable people, exposing the under-criminalization of state-corporate crime, despite its harmful effects. The failure of the federal and state governments to exercise appropriate regulatory oversight on the production, distribution and marketing of OxyContin was a core contributory element in the epidemic of opioid addiction and deaths by overdoses (Griffin and Miller 2010).

On the retail level, pharmacies and pain clinics were complicit in selling vast numbers of these opioids, absent any legitimate medical oversight (Eyre 2020). By May 2020, the role of major pharmacy chains such as CVS and Rite-Aid in the opioid epidemic was getting more attention (Hoffman 2020). Since 2003, far more people in the United States died prematurely from prescription drugs - opioid analgesics - than from heroin and cocaine combined (Paulozzi et al. 2012). Overdoses involving opioids killed more than 47,000 people in 2017 , and 36 percent of those 
deaths involved prescription opioids (CDC 2020a). The overall opioid prescribing rate in 2018 was 51.4 prescriptions per 100 people, meaning that one of every two U.S. citizens has been legally prescribed drugs (CDC 2020b). More striking is that some U.S. counties had rates that were six times higher than that.

All-too-many medical researchers and physicians are corrupted by the pharmaceutical industry, obtaining lucrative speaker and consulting fees, outright gifts and bribes, and other direct and indirect financial benefits from the industry in return for promoting drugs in their research publications and by over-prescribing, including for "off-label" uses (Ornstein and Thomas 2018; Posner 2020). In the profit-focused private enterprise system of which the pharmaceutical industry is a part, there are really no effective controls on pricing and as many such products are deemed "needed" and paid for partly if not wholly by third parties (i.e., health insurance plans) vastly inflated prices are pursued. Many outrageous mark-ups of pharmaceutical products could be cited. In one case, the drugs needed by a single family with several members afflicted with a rare bone disease cost some $\$ 6$ million annually, with most of that cost paid through an employer-based health plan (and accordingly borne by its members) (Thompson and Abelson 2019). In a recent six-year period, prescription drug prices rose at a rate that was about four times the rate of inflation, and with no obvious rationale aside from the pursuit of exorbitant profits (Posner 2020). In fact, the very high cost of pharmaceutical drugs - with at least some portion of that cost borne directly by U.S. consumershad become such a high-profile concern by the second decade of the twenty-first century that President Trump announced that his administration would take on this issue (New York Times 2019; Weiland 2020). To date-perhaps at least in part due to the immense political clout of the pharmaceutical industry and its ties to the administration - this has not happened.

The range of harms associated with the pharmaceutical industry exemplify statecorporate crime, because they are only possible as a consequence of the multiple, cooperative ties between public and private sector entities, or government power brokers and corporate decision-makers. Political office holders benefit in many different ways from doing the bidding of the pharmaceutical industry, including but hardly limited to generous campaign donations. To exemplify, in March, 2020 the U. S. Congress passed legislation including an allocation of over \$3 billion to produce and develop drugs and vaccines for COVID-19, and the pharmaceutical industry successfully lobbied to weaken or prevent the inclusion of measures to control the pricing of such drugs (Zaitchik 2020). Something parallel occurred when the Obama administration's Affordable Care Act was adopted. In effect, taxpayers have long subsidized the development of drugs that the pharmaceutical industry then grossly overcharges them for as patients. By mid-summer 2020, pharmaceutical company insiders were cashing in on the desperate pursuit of a COVID-19 vaccine 
(Gelles and Drucker 2020). They were selling off their stock options whose values had risen dramatically following the announcement that their pharmaceutical company was making progress in this pursuit.

Let us be clear. The U.S. pharmaceutical industry is filled with many people, on many different levels, working hard to produce pharmaceutical products that are beneficial in some way to tens of millions of citizens, in some cases making it possible for them to live pain-free, productive lives, and saving their lives (Saphier 2020). There are many good people among them. Our point here is that the core structure and organization of the pharmaceutical industry is such that it is inherently a form of state-corporate crime, with a broad range of hugely harmful consequences suggested above. The transformation of the production and disposition of pharmaceutical products into a form wholly marginalizing if not completely eliminating these criminogenic dimensions requires recognition of the true nature of this existing industry. Stripping out the profit-seeking dimension of the pharmaceutical industry - in effect, recognizing that what it produces is aligned with a core right of human beings in relation to the pursuit of good health - would go a long way toward removing the criminogenic character of this industry. If it were possible for the industry as presently constituted to demonstrate that it has made significantly better health and mortality outcomes for U.S. citizens than is true for other advanced countries, that would be one thing, but as we have noted earlier that is far from the case. Even though the management of an eventual vaccine and treatments for COVID-19 is yet far from clear, it seems virtually inevitable that the pharmaceutical industry will approach a COVID-19 solution with its institutionalized, criminogenic, profit-maximizing focus.

\section{The Health Care Industry and Exploitation of the Coronavirus Pandemic Crisis}

There is a long history of private enterprise - including major corporations - finding ways to profit from natural disasters (Mutter 2015). Early in the coronavirus pandemic crisis efforts to profit from it in various ways emerged, with health care entrepreneurs and enterprises as part of this. These endeavours related to attempts to take advantage of shortages of ventilators and other essential supplies and equipment and of testing, in addition to the corrupt efforts of well-connected and wellfunded health care providers to obtain government aid (Bradley 2020; Wu 2020). Political insiders within the government were in some cases directly attempting to facilitate and take advantage of such opportunities (Vogel 2020). It was quite clear that much state-corporate crime was being initiated at the outset of the crisis.

More specifically, a significant potential exists for the pharmaceutical industry to exploit the COVID-19 crisis: for example, with price gouging or price-fixing for 
essential pharmaceutical drugs; for false claims about the effectiveness of pharmaceutical products to combat COVID-19 infections; and for anti-trust practices to monopolize control of essential pharmaceutical products; and in relation to the search for and ultimate pricing of a vaccine (Kaplan et al. 2020; Mazzucato and Momenghalibat 2020; Thomas and Grady 2020). Should such practices occurand be broadly exposed - they would be quite certain to inspire formidable public outrage. Historically, the pharmaceutical industry has had considerable success in limiting or deflecting public outrage over some of its more pernicious practices. It remains to be seen whether that would be true within the context of an on-going COVID-19 pandemic crisis.

One striking, illustrative case of attempting to exploit for profit the pandemic crisis involved Gilead Sciences (Zaitchik 2020). This pharmaceutical company, with ties to the Trump administration, claimed "orphan status" for Remdesivir, a drug currently used to treat those with COVID-19. The orphan drug status provides a seven-year-market exclusivity period along with other tax benefits. Historically, and by design, orphan status is only applied to drugs for treating rare diseases affecting less that 200,000 people. Gilead applied for orphan status when COVID-19 affected less than this threshold in the U.S., but with full awareness of the immediate spread of the virus that would follow (Kohrman 2020). It was not the Trump Administration - in charge of taking care of the health of the U.S. population - that stopped this outrage. Civil associations, including Public Citizen, a consumer-rights advocacy group, and 50 other organizations, were the ones that denounced Gilead's use of "a loophole in the law to profiteer off a deadly pandemic" (Public Citizen 2020), forcing the corporation to withdraw its request (Gilead 2020). Rather than privileging public well-being, at least some parts of the U.S. pharmaceutical industry-with complicity on the part of the Trump administration - privileged maximizing of profits, which might result in deprivation of access to a COVID-19 cure for those who cannot afford it. An estimated 27.5 million Americans who do not have health insurance coverage would be especially vulnerable in this regard.

\section{Concluding Thoughts: Thinking about Crime-and Re-imagining the Criminological Future}

How might deaths from COVID-19 be understood in relation to crime? Indeed, what proportion of those who died was due principally, if not exclusively, to the negligent policies and practices of governmental and corporate leadership, from the president of the United States down? In May, 2020, the New York Times headlined a frontpage story with "Lockdown Delays Cost at Least 36,000 Lives, Data Suggest" (Glanz and Robertson 2020). If this claim holds up, tens of thousands of people in 
the United States - just through this period — need not have lost their lives had the public and private sector leadership taken the right steps, policy-wise, early on. Are they best classified as victims of a crime, then? And looking forward, if the statecorporate alliance between Gilead Sciences and the Trump administration to develop a cure for COVID-19 succeeds, shall we consider those millions of people without access to the drug also as victims of crime? It should be clear that, when millions of people face death as a result of state-corporate actions or omissions, a critical criminology perspective on health criminology is an urgent task for state crime studies.

In the spring of 2020, fairly early in the pandemic, the observation that this crisis could "turn our world upside down" was being made. That capitalism itself is a source of huge and devastating forms of harm has been well-documented (Chang 2010; Shaxson 2019). As of this writing (during summer 2020) it is too early to say whether the impact of the crisis will foster enduring, structural changes in the political economy, society and culture, or only more cosmetic and largely temporary ones. The pandemic crisis, at a minimum, exposed the precariousness of the financial circumstances of tens of millions of people in the world's richest country. It demonstrated in full the massive interdependency of members of society, and further discredited a myth of "rugged individualism" as the key source of success and prosperity. It highlighted, more specifically, who the really "essential" workers in our society are, meaning the frontline health care workers, food store employers, teachers, drivers, sanitation workers and so forth. And that such workers are all-too-often under-appreciated and undercompensated. Altogether, the COVID-19 pandemic brought into sharp relief many core deficiencies and distortions within the existing political economy and social order.

Even if the full scope of the impact of this pandemic is not yet wholly known, we submit here that the COVID-19 pandemic crisis could - and indeed shouldbring about a long overdue transformation in the field of criminology. The formidable growth of support for fundamental social change in relation to the existing political economy and openness to socialistic policies, especially by the younger generation, strongly suggests that traditional political — and criminologicalframeworks will be increasingly rejected. The monopolistic role of enterprises such as Google, Facebook, Apple and Amazon in conjunction with political or governmental interests in various dysfunctional dimensions of contemporary social existence is being increasingly recognized. Such recognition should align with greater receptivity within criminology to the significance of the state-corporate crime concept and, within it, of a critical health criminology. The pandemic has brought into especially sharp relief the interdependency of state and private sector organizational actors, and accordingly, state-corporate crime in relation to the health care and pharmaceutical industries. The COVID-19 crisis has exposed some of the most substantial sources of harm to human beings, and they do not 
come from conventional criminal offenders. Both the actions and the failures to act on the part of the powerful (and the rich) - in the public and the private sectors - greatly amplified the loss of life along with a vast range of other forms of suffering that emanated out of the pandemic. Criminology as a field, through the first two decades of the twenty-first century, has continued to privilege attention to the crimes of the poor and the powerless - and the control of such crime- over the crimes of the rich and the powerful. Critical criminology, over the course of the past half century or so (originating, in the United States as radical criminology), has systematically exposed the broad range of harms associated with domination, oppression and inequality, within the context of a capitalist political economy. During this same period, far more substantial attention to crimes of the powerful (rooted in the work of Sutherland and others) has documented the huge scope of harm from such crime, and the more limited accountability for such crime relative to that imposed upon conventional crime. Over the past 30 years or so in particular, in addition to a substantial growth of attention to corporate crime, we have seen the emergence within criminology of significant attention to crimes of states, to state-corporate crime, to crimes within the financial sector, to crimes of globalization, and related manifestations of crimes of the powerful. In a special issue of the newly established Journal of White Collar and Corporate Crime, the specific criminological consequences of the Trump administration's regulatory rollback - an inherently state-corporate crime enterprise-were addressed (Michalowski 2020). It may also be worth noting that between 2014 and 2020, six of the seven presidents of the American Society of Criminology were women, one being a woman of colour, two being associated with critical criminology, and one (the current president) being a leading white-collar crime scholar. Meda ChesneyLind (2020), the 2019 president, chose "[f]eminist criminology in an era of misogyny" as the topic of her presidential address. Chesney-Lind, a self-described feminist activist, highlighted the on-going importance of criminological attention to gender, sexism and racism, and specifically of embracing reproductive justice as a criminological concern, along with a call for more attention to newsmaking or public criminology. Sally Simpson (2019), the 2020 president, was planning to highlight issues of corruption in her presidential address. In a similar vein, the president of the British Society of Criminology in 2020, Sandra Walklate, has published extensively on criminology of war, and on intimate partner violence. In turn, the vice president of the British Society of Criminology, Pamela Davies, was a co-editor of Invisible Crimes and Social Harms (Davies et al. 2014). The foregoing represents a very selective "snapshot" of how a field of criminology long dominated by white men focused principally upon conventional forms of crime is in fact undergoing some significant change, going forward. If the COVID-19 pandemic crisis emerging at the beginning of the third decade of the twenty-first 
century contributes to a paradigmatic shift within criminology, one that privileges attention to the crimes of the powerful and rich over those of the powerless and poor, that would be something beneficial coming out of these dreadful times.

\section{References}

Abelson, R. (2020) "Doctors Without Patients: Small Practices in Peril as Business Stalls", New York Times, 7 May. Available online at: www.nytimes.com/2020/05/05/health/coronavirus-primarycare-doctor.html (accessed 10 June 2020).

Appel, J. M. (2011) “Health 'Insurance': A Criminal Enterprise”, HuffPost, 25 May. Available online at: www.huffpost.com/entry/health-insurance-a-crimin_b_341448 (accessed 10 June 2020).

Aronoff, K., Dreier, P., and Kazin, M. (eds) (2020) We Own the Future: Democratic Socialism American Style. New York: The New Press.

Barak, G. (ed.) (2015) The Routledge International Handbook of the Crimes of the Powerful. New York: Routledge.

Bittle, S., Snider, L., Tombs, S., and Whyte, D. (eds) (2018) Revisiting Crimes of the Powerful: Marxism, Crime and Deviance. New York: Routledge.

Bogdanich, W. (1991) The Great White Lie: Dishonesty, Waste, and Incompetence in the Medical Community. New York: Touchstone.

Bolus, K. (2020) “Moses Taylor Disputes Nurses' Claims in Report”, Sunday Times-Tribune, 12 April. Available online at: www.newsbreak.com/pennsylvania/scranton/news/0OjMJIzV/moses-taylordisputes-nurses-claims-in-report (accessed 10 June 2020).

Bradley, J. (2020) "Companies Cash in on Scarce Blood Samples Donated by Survivors", New York Times, 20 May. Available online at: www.nytimes.com/2020/05/01/world/europe/coronavirusblood-samples.html (accessed 10 June 2020).

Braithwaite, J. (1984) Corporate Crime in the Pharmaceutical Industry. London: Routledge.

Brill, S. (2015) America's Bitter Pill: Money, Politics, Backroom Deals, and the Fight to Fix Our Broken Healthcare System. New York: Random House.

Business Insider (2020) Gilead got FDA approval to keep its experimental coronavirus treatment exclusive for 7 years, 24 March. Available online at: www.businessinsider.com/gileads-potentialcoronavirus-treatment-gets-fdas-orphan-drug-label-2020-3?r=DE\&IR=T (accessed 10 June 2020).

Butler, D. (2020) "Anguished Nurses Say Pennsylvania Hospital Risked Infecting Cancer Patients, Babies and Staff with Covid-19", The Washington Post, 11 April. Available online at: www. washingtonpost.com/health/2020/04/11/amid-chaos-anguished-nurses-say-pennsylvania-hospitalrisked-infecting-cancer-patients-babies-staff/ (accessed 10 June 2020).

Case, A. and Deaton, A. (2020a) Deaths of Despair and the Future of Capitalism. Princeton: Princeton University Press.

Case, A. and Deaton, A. (2020b) “America Can Afford a World-Class Health System. Why Don't We Have One?", New York Times, 18 April. Available online at: www.nytimes.com/2020/04/14/ opinion/sunday/covid-inequality-health-care.html (accessed 10 June 2020).

Caulkins, J. P. and Reuter, P. (2017) "Dealing More Effectively and Humanely with Illegal Drugs", in Tonry, M., Nagin, D. S., eds. Reinventing American Criminal Justice. Chicago: University of Chicago Press.

CDC (2020a) America's Drug Overdose Epidemic: Data to Action. Available online at: www.cdc.gov/ injury/features/prescription-drug-overdose/index.html (accessed 10 June 2020). 
CDC (2020b) U.S. Opioid Prescribing Rate Maps. Available online at: www.cdc.gov/drugoverdose/ maps/rxrate-maps.html (accessed 10 June 2020).

Chambliss, W. J., Michalowski, R., and Kramer, R. C. (eds) (2010) State Crime in the Global Age. Portland, OR: Willan.

Chang, H. J. (2010) 23 Things They Don't Tell You About Capitalism. London: Penguin.

Chesney-Lind, M. (2019) "Criminology in the New Era: Confronting Injustice and Inequalities", The Criminologist, 44: 3-4.

Chesney-Lind, M. (2020) "Feminist Criminology in an Era of Misogyny", Criminology, 58 (August): 407-422.

Davies, P., Francis, P., and Wyatt, T. (eds) (2014) Invisible Crimes and Social Harms. New York: Palgrave MacMillan.

DeKeseredy, W., and Dragiewicz, M. (eds) (2018) Routledge Handbook of Critical Criminology. 2nd edition. New York: Routledge.

Drucker, J., Silver-Greenberg, J., and Kliff, S. (2020) "How Wealthiest Hospitals Reaped Billions in Bailout", New York Times, 26 May. Available online at: www.nytimes.com/2020/05/25/business/ coronavirus-hospitals-bailout.html (accessed 10 June 2020).

Eyre, E. (2020) Death in Mud Lick: A Coal Country Fight Against the Drug Companies That Delivered the Opioid Epidemic. New York: Scribner.

Fattah, E. (2020) “A Social Scientist Looks at a Global Crisis”, Special Paper: School of Criminology, Simon Fraser University, 30 April. Available online at: https://vancouversun.com/opinion/ezzat-afattah-a-social-scientists-view-of-a-global-crisis (accessed 10 June 2020).

Frankel, T., and Roma, T. (2020) "Historical Financial Decline Hits Doctors, Dentists, and Hospitals - Despite Covid-19", Washington Post, 4 May. Available online at: www.washingtonpost.com/ business/2020/05/04/financial-distress-among-doctors-hospitals-despite-covid-19-weighs-heavilyeconomy/ (accessed 10 June 2020).

Friedrichs, D. O. (2007) “Transnational Crime and Global Criminology: Definitional, Typological, and Contextual Considerations", Social Justice, 24(2): 4-18.

Friedrichs, D. O. (2010) Trusted Criminals: White Collar Crime in Contemporary Society. 4th ed. Belmont, CA: Wadsworth/Cengage.

Friedrichs, D. O. and Rothe, D. L. (2014) "State-Corporate Crime and Major Financial Institutions: Interrogating an Absence", State Crime, 3(2): 146-152.

Gelles, D. and Drucker, J. (2020) "With Well-Timed Bets, Insiders Cash In on Sprint for a Vaccine", New York Times, 26 July.

Ghazi-Tehrani, A. (2019) "Corporate Crime and the State", in H. Pontell (ed.) Oxford Research Encyclopedia of Criminology and Criminal Justice. New York: Oxford University Press.

Gilead (2020) "Gilead Sciences Statement on Request to Rescind Remdesivir Orphan Drug Designation". Available online at: www.gilead.com/-/media/gilead-corporate/files/pdfs/companystatements/remdesivir-orphan-drug-designation.pdf (accessed 10 June 2020).

Glanz, J. and Robertson, C. (2020) “Lockdown Delays Cost at Least 36,000 Lives, Data Suggest”, New York Times, 21 May. Available online at: www.nytimes.com/2020/05/20/us/coronavirus-distancingdeaths.html (accessed 10 June 2020).

Goldacre, B. (2013) Bad Pharma: How Drug Companies Mislead Doctors and Harm Patients. New York: Faber and Faber.

Goldstein, M., Silver-Greenberg, J., and Gebeloff, R. (2020) "Push for Profits Left Nursing Homes Struggling to Provide Care", New York Times, 7 May. Available online at: www.nytimes. com/2020/05/07/business/coronavirus-nursing-homes.html (accessed 10 June 2020). 
Gordon, N. and Green, P. (2020) "The Acceleration of Death Precipitated by Covid-19 Exposes State Crime", Open Democracy, 21 April.

Green, P. and Ward, T. (2004) State Crime. London: Pluto.

Griffin, O. H. and Miller, B. L. (2010) "OxyContin and a Regulation Deficiency of the Pharmaceutical Industry: Rethinking State-Corporate Crime", Critical Criminology, 19(3): 213-226.

Hagan, J. (2010) Who Are the Criminals? The Politics of Crime Policy from the Age of Roosevelt to the Age of Reagan. Princeton, NJ: Princeton University Press.

Hakim, D., Rabin, R. C., and Rashbaum, W. K. (2019) "Lawsuits Lay Bare Sackler Family Role in Opioid Crisis", New York Times, 1 April. Available online at: www.nytimes.com/2019/04/01/ health/sacklers-oxycontin-lawsuits.html (accessed 10 June 2020).

Hillyard, P., Pantazis, C., Tombs, S., and Gordon, D. (2004) Beyond Criminology: Taking Harm Seriously. London: Pluto Press.

Hsiao, W. C. (2020) "How to Fix American Health Care", Foreign Affairs (January/February): 96-106. Hoffman, J. (2020) "Big Pharmacy Chains Accused of Own Role in Opioid Epidemic", New York Times, 28 May. Available online at: www.nytimes.com/2020/05/27/health/opioids-pharmacy-cvslitigation.html (accessed 10 June 2020).

Kaplan, S., Goldstein, M., and Stevenson, A. (2020) “Trump's Vaccine Chief Has Vast Ties to Drug Industry, Posing Possible Conflicts", New York Times, 20 May. Available online at: www.nytimes. com/2020/05/20/health/coronavirus-vaccine-czar.html (accessed 10 June 2020).

Kliff, S. (2020) "Hospitals Knew How to Make Money. Then Coronavirus Happened", New York Times, 15 May. Available online at: www.nytimes.com/2020/05/15/us/hospitals-revenue-corona virus.html (accessed 10 June 2020).

Kohrman, N. (2020) "Bitter Pill”, Mother Jones, (July/August): 46-47.

Lerner, S. (2020) "Big Pharma Prepares to Profit from the Coronavirus", The Intercept, 13 March. Available online at: theintercept.com/2020/03/13/big-pharma-drug-pricing-coronavirus-profits/ (accessed 05 December 2020).

MacFarquhar, N., and Kovaleski, S. F. (2020) “A Pandemic Bright Spot: In Many Places, Less Crime”, New York Times, 27 May. Available online at: www.nytimes.com/2020/05/26/us/coronaviruscrime.html (accessed 10 June 2020).

Macy, B. (2018) Dopesick: Dealers, Doctors, and the Drug Company that Addicted America. New York: Little Brown.

Mazzucato, M. and Momenghalibaf, A. (2020) “Drug Companies Will Make a Killing from Coronavirus", New York Times, 18 March. Available online at: www.nytimes.com/2020/03/18/opinion/coronavirusvaccine-cost.html (accessed 10 June 2020).

McNeil, D. B. Jr., and Jacobs, A. (2020) "Rebuking China, Trump Curtails Ties to Hong Kong and Severs Them With W.H.O.", New York Times, 29 May. Available online at: www.nytimes. com/2020/05/29/us/politics/trump-hong-kong-china-WHO.html (accessed 10 June 2020).

Metcalf, T., Hill, H., and Vickers, E. (2019) "How the Sackler Family Shifted Billions from Opioids to Trusts", Bloomberg News, 17 December. Available online at: www.bloomberg.com/news/ articles/2019-12-17/how-the-sackler-family-shifted-billions-from-opioids-to-trusts (accessed 10 June 2020).

Michalowski, R. (1996) "Critical Criminology and the Critique of Domination: The Story of an Intellectual Movement", Critical Criminology, 7(1): 9-16.

Michalowski, R. (2009) "Power, Crime and Criminology in the New Imperial Age", Crime, Law \& Social Change, 51: 305-325.

Michalowski, R. (2020) “Trump's Regulatory Reset: Corporate Crime and Social Harm in an Age of Neo-Liberal Deregulation", Journal of White Collar and Corporate Crime, 1(2): 83-155. 
Michalowski, R. and Brown, M. (2020) "Poisoning for Profit: Regulatory Rollback, Public Health, and State-Facilitated Corporate Crime", Journal of White Collar and Corporate Crime, 1(2): $113-122$.

Michalowski, R. J. and Kramer, R. (eds.) (2006) State-Corporate Crime. New Brunswick, NJ: Rutgers University Press.

Mutter, J. C. (2015) Disaster Profiteers: How Natural Disasters Make the Rich Rich and the Poor Even Poorer. New York: St. Martin's Press.

New York Times (2019) "Sound, Fury and Prescription Prices", 7 July. Available online at: www. nytimes.com/2019/07/06/opinion/drug-pricing-trump.html (accessed 10 June 2020).

Nussbaum, B. (1990) Good Intentions: How Big Business and the Medical Establishment are Corrupting the Fight Against AIDS, Alzheimer's, Cancer, and More. New York: Penguin.

Ornstein, C. and Thomas, K. (2018) "Broken System Lets Doctors Omit Industry Ties in Journals", New York Times, 9 December.

Paulozzi, L., Baldwin, G., Franklin, G., Kerlikowske, G., Jones, C., Pharm D, Ghiya, N. and Popovic, T. (2012) "CDC Grand Rounds: Prescription Drug Overdoses", Morbidity and Mortality Weekly Report, 61(1): 10-13.

Porter, E. (2020) "Why America Will Never Get Medicare for All", New York Times, 15 May. Available online at: www.nytimes.com/2020/03/14/sunday-review/medicare-for-all-americaracism.html (accessed 10 June 2020).

Posner, G. (2020) Pharma: Greed, Lies, and the Poisoning of America. New York: Avid Reader.

Public Citizen (2020) Gilead Must Relinquish Monopoly on Potential Coronavirus Treatment, March 25. Available online at: www.citizen.org/news/gilead-must-relinquish-monopoly-onpotential-coronavirus-treatment/(accessed 10 June 2020).

Reiman, J. and Leighton, P. (2020) The Rich Get Richer and the Poor Get Prison. 12th ed. New York: Routledge.

Reiner, R. (2016) Crime. Malden, MA: Polity Press.

Rorie, M. (ed.) (2020) The Handbook of White-Collar Crime. New York: Wiley.

Rosenfeld, R. (2011) "The Big Picture: 2010 Presidential Address to the American Society of Criminology", Criminology, 49(10): 1-26.

Rosenthal, E. (2020) "We Knew the Coronavirus Was Coming, Yet We Failed", New York Times, 6 May. Available online at: www.nytimes.com/2020/05/06/opinion/coronavirus-health-care-market. html (accessed 10 June 2020).

Rothe, D. L. (2009) State Criminality: The Crime of All Crimes. Lanham, MD: Rowman \& Littlefield. Rothe, D. L. and Friedrichs, D. O. (2015) Crimes of Globalization. London: Routledge.

Rothe, D. L. and Kauzlarich, D. (eds.) (2016a) Towards a Victimology of State Crime. New York: Routledge.

Rothe, D. L. and Kauzlarich, D. (2016b) Crimes of the Powerful: An Introduction. London: Routledge. Ruggiero, V. (2015) Power and Crime. New York: Routledge.

Sanger-Katz, M. (2020) "Why 1.4 Million Health Jobs Have Been Lost During a Huge Health Crisis", New York Times, 8 May. Available online at: www.nytimes.com/2020/05/08/upshot/health-jobsplummeting-virus.html (accessed 10 June 2020).

Saphier, N. (2020) Make America Healthy Again: How Bad Behavior and Big Government Caused a Trillion-Dollar Crisis. New York: Broadside Books.

Schwartz, M. D. and Brownstein H. H. (2016) "Critical Criminology", in Piquero, A. (ed.) The Handbook of Criminological Theory. New York: Wiley Blackwell.

Shaxson, N. (2019) The Financial Curse: How Global Finance is Making Us All Poorer. New York: Grove. 
Silver-Greenberg, J., Drucker, J., and Enrich, D. (2020a) “After Billions in Aid, Layoffs Follow”, New York Times, June 8.

Silver-Greenberg, J., Enrich, D., Drucker, J., and Cowley, S. (2020b) "Large Companies Take Bailout Aid in Dubious Gains", New York Times, 27 April. Available online at: www.nytimes. com/2020/04/26/business/coronavirus-small-business-loans-large-companies.html (accessed 10 June 2020).

Simpson, S. (2019). Personal communication.

Slobodian, Q. (2020) "The Vulture Capitalists are Counting on Us to Do Nothing", The Nation, 20 April. Available online at: www.thenation.com/article/society/coronavirus-vulture-capitalism/ (accessed 10 June 2020).

Sparrow, M. (2007) License to Steal: Why Fraud Plagues America's Health Care System. Boulder, CO: Westview Press.

Tavernis, S. (2020) "Will the Coronavirus Kill What's Left of Americans' Faith in Washington?", New York Times, 23 May. Available online at: www.nytimes.com/2020/05/23/us/coronavirus-governmenttrust.html (accessed 10 June 2020).

Thomas, K. and Abelson, R. (2019) "Drug to Treat Disease to Cost Millions", New York Times, 26 August. Available online at: www.nytimes.com/2019/08/25/health/drug-prices-rare-diseases.html (accessed 10 June 2020).

Thomas, K. and Grady, D. (2020) "How Upbeat Vaccine News Fueled a Stock Surge, and an Uproar", New York Times, 24 May. Available online at: www.nytimes.com/2020/05/23/health/coronavirusvaccine-moderna.html (accessed 10 June 2020).

Thompson, D. (2020) "What's Behind South Korea's Covid-19 Exceptionalism?", The Atlantic, 6 May. Available online at: www.theatlantic.com/ideas/archive/2020/05/whats-south-koreassecret/611215/ (accessed 10 June 2020).

Thompson, K. and Abelson, R. (2019) “The \$6 Million Drug Claim.”, New York Times, 25 August. Available online at: www.nytimes.com/2019/08/25/health/drug-prices-rare-diseases.html (accessed 10 June 2020).

Tombs, S. (2012) "State-Corporate Symbiosis in the Production of Crime and Harm", State Crime, 1(2): 170-195.

Topalli, V. and Nikolovska, M. (2020) "The Future of Crime: How Crime Exponentiation Will Change Our Field", The Criminologist, 45(3): 1-8.

Ugwudike, P. (2015) An Introduction to Critical Criminology. Bristol: Policy Press.

Vaughn, M. G., Jackson, D. B., Testa, A., Holzer, K., Jaegers, L., and Semenza, D. C. (2020) "Health Criminology: New Developments in an Emerging Paradigm", The Criminologist, 45(3): 9-13.

Vegh Weis, V. (2017) Marxism and Criminology: A History of Criminal Selectivity. Leiden: Brill.

Vogel, K. (2020) “Firm Set Up by G.O.P. Operatives Under Scrutiny Over Virus Contracts”, New York Times, 6 May.

Weiland, N. (2020) “As the Coronavirus Spreads, Legislation on Drug Pricing Remains Stalled.”, New York Times, 28 June.

Wu, T. (2020) “A Corporate Merger Cost Us Ventilators”, New York Times, 13 April. Available online at: www.nytimes.com/2020/04/12/opinion/ventilators-coronavirus.html (accessed 10 June 2020).

Zaitchik, A. (2020) "No Vaccine in Sight", The New Republic, June: 21-29.

Zorn, J. (2015) "Big Pharma: Life Saver or Criminal Enterprise", Universal Health Care. Available online at: https://universalhealthct.org/big-pharma-life-saver-or-criminal-enterprise/ (accessed 10 June 2020). 